\title{
Comparative Performance of Vanaraja, Gramapriya and Indigenous Desi Bird under Backyard System of Rearing in Jammu Province, India
}

\author{
P. Singh, D. Kachroo, N.P. Thakur, V. Khajuria, P. Kumar, \\ Mahesh Kumar ${ }^{*}$ and G. Kour \\ Block No. 3, Farming System Research Centre. SKUAST -Jammu, J\&K, India \\ *Corresponding author
}

\begin{tabular}{l} 
Ke y w o r d s \\
$\begin{array}{l}\text { Vanaraja, Gramapriya, } \\
\text { backyard system, Egg } \\
\text { production, Body } \\
\text { weight, Hatchability, } \\
\text { Mortality }\end{array}$ \\
\hline Article Info \\
$\begin{array}{l}\text { Accepted: } \\
\text { 04 January } 2018 \\
\text { Available Online: } \\
\text { 10 February } 2018\end{array}$ \\
\hline
\end{tabular}

\section{Introduction}

Poultry farming is one of the fastest growing segments of agriculture in India. It carries a pivotal position in current Indian economy and has evolved as an extremely business oriented enterprise Sreenivas et al., (2013). Improvement in poultry performance started from 1950s together with selection of genetically superior birds and improvement in ambient factors such as feeding and housing, which resulted in decrease slaughtering age to 42 days and increase body weight to $2 \mathrm{~kg}$
Havenstien et al., (1994) High environmental temperatures during summer months significantly reduce feed intake and causes slower growth rates of poultry Bonnet et al., (1997). Heat stress depresses body weight and is generally accompanied by suppression of feed intake leading to decline in production. Vanaraja is an example of superior stock (developed by the Project Directorate on Poultry, ICAR, Hyderabad for backyard farming in rural and tribal areas of India) a choice dual purpose coloured bird which have significantly contributed to the overall 
economy of the rural people in terms of eggs and meat (Bhattacharya et al., 2005). Gramapriya a layer type variety developed for free range farming in rural and tribal areas. Peoples of Jammu province are mostly rural and tribal masses have been keeping poultry by tradition for their livelihood and nutritional security since the time of immemorial. Majority of the farmers are still keeping 10-15 numbers of low input indigenous fowls at their backyard for both egg and meat production to meet their day to day petty expenses and nutritional security. However, the productivity of native indigenous fowls is very low due to their inherent low genetic potential. Vanaraja, a dual type high yielding chicken developed by Project Directorate on Poultry, Hyderabad and successfully introduced in various parts of our country is giving promising productive and reproductive performance under backyard system of management. However, information on systemic studies on the productive and reproductive performance of Vanaraja and Gramapriya birds under backyard system in Jammu province is very scanty. Keeping in view, the present study has been undertaken to assess various economic traits of Vanaraja and Gramapriya birds under extensive system of rearing in Jammu province.

\section{Materials and Methods}

The present study has been undertaken at Research Farm, Farming System Research Centre, SKUAST- J to evaluate production efficiency of three types of chickens varieties (Vanaraja, Gramapriya and local birds 100 each) upto 60 weeks of age during September (2013-2016). In the backyard system the birds were reared under extensive as well as semi intensive care. The birds were kept in locally made house of available material for night stay. There were lots of similarities in feeding habits of all these birds like forage and scratch feed from vast backyard with green leafy vegetables, insects and grains of grass.
Sometimes the birds were offered with chopped kitchen waste, and other household vegetable waste. These birds were fed with these feeds both morning and evening. Except offering some feed material, no extra care was given to them. The birds were vaccinated against Ranikhet and Gumboro diseases by following standard vaccination method. Age of the birds at first egg stage was recorded. Observations were also recorded for other parameters viz. total egg production, first egg weight and shank length $(\mathrm{mm})$ of adult male and female birds. Performance of these birds was evaluated using various tests. Means and standard errors of various traits were calculated using standard statistical procedures (Snedecor and Cochran, 1989).

\section{Results and Discussion}

Both the improved varieties had significantly $(\mathrm{P} \leq 0.01)$ higher body weight (Table 1) than local chicken. Among improved varieties Vanaraja were heavier $(\mathrm{P} \leq 0.05)$. Age of first egg (Table 2) was significantly lower $(\mathrm{P} \leq 0.05)$ in Gramapriya $(173.00 \pm 1.35$ days $)$ in comparison to Vanaraja (181.53 \pm 1.29 days) and desi birds (179.87 \pm 1.48 days). Kalita $e t$ al., (2012) also reported almost similar body weight of indigenous chicken at 40 weeks of age all previous studies have reported that Vanaraja was heavier than Gramapriya Haunshi et al., (2009). All the backyard Vanaraja got better body weight than other two varieties and thus proved its better genetic potential to convert available feed into quality animal protein. Gramapriya is predominantly an egg producing variety developed at project Directorate on poultry, Hyderabad and thus lower age of sexual maturity was justifiable. Kumar et al., (2005) reported that age at sexual maturity was 171 days for Vanaraja chicken while Bhattacharya et al., (2005) reported that the age at sexual maturity and average egg size of Vanaraja chicken ranged from 172 to 185 days and between 46 and $55 \mathrm{~g}$ 
respectively. In present study compared to Gramapriya relatively higher age of first egg was observed in Vanaraja when compared to Gramapriya the relatively lower body weights and higher age at sexual maturity of improved varieties observed in studies may be due to climatic conditions of Jammu province.

The study revealed that the Gramapriya was considerably $(\mathrm{P} \leq 0.05)$ more consistent in laying compared to other to groups, while Vanaraja was better $(\mathrm{P} \leq 0.05)$ than local. The present result on total egg production was much lower than the reports of (Malik and Singh, 2009) who found 62.55 and 30.13 numbers of total egg production at 40 weeks of age in Gramapriya and Vanaraja, respectively at farm at ICAR Tripura centre. In contrast to the present findings, Niranjan et al., (2008) and Ramana et al., (2010) recorded higher body weight of Vanaraja birds at different ages under intensive system of management. The higher body weight in intensive system might be due to the supplementation of balanced diet and other proper managemental care. According to survey data 30 to $35 \%$ eggs were sold, 40$45 \%$ ware consumed and rest were set for hatching by local broody hen. Overall $60 \%$ hatchability was recorded. During the study period 14.5, 11.7 and 21.2 per cent mortality were recorded in Gramapriya, Vanaraja and local birds respectively (Fig. 1).

The average weight of first egg and egg weight at 40 and 60 weeks of age were significantly low in local birds. Shank length in female birds for all three groups were statistically similar but significantly higher $(\mathrm{P} \leq 0.05)$ shank length was recorded in male birds of Gramapriya followed by Vanaraja and local birds.

Table.1 Mean body weight (g) of birds at different age (wks) of birds

\begin{tabular}{|c|c|c|c|}
\hline Age in weeks & Localldesi breeds (n 100) & Gramapriya (n & Vanaraja (n 100) \\
\hline 10 & $370.00 \pm 0.31$ & $776.75 \pm 6.33$ & $954.50 \pm 10.23$ \\
\hline 15 & $646.50 \pm 9.52$ & $954.50 \pm 10.23$ & $1227.00 \pm 14.82$ \\
\hline 20 & $1068.00 \pm 25.64$ & $1499.50 \pm 21.55$ & $1748.50 \pm 31.92$ \\
\hline 25 & $1347.00 \pm 14.46$ & $1734.50 \pm 23.00$ & $2107.00 \pm 30.52$ \\
\hline 40 & $1579.50 \pm 19.59$ & $2031.75 \pm 26.14$ & $2280.00 \pm 35.06$ \\
\hline 60 & $1697.50 \pm 28.21$ & $2177.50 \pm 30.67$ & $2422.50 \pm 30.24$ \\
\hline
\end{tabular}

Table.2 Average age of first egg, total egg production, first egg weight and shank length (mm) of adult male and female birds

\begin{tabular}{|l|l|l|l|}
\hline Parameters & Local birds & Gramapriya & Vanaraja \\
\hline Age of first egg(d) & $179.87 \pm 1.48$ & $173.00 \pm 1.35$ & $\mathbf{1 8 1 . 5 3 \pm 1 . 2 9}$ \\
\hline Total eggs upto 40 weeks of age(No.) & $15.33 \pm 0.54$ & $30.40 \pm 1.06$ & $\mathbf{2 2 . 2 0 \pm 0 . 8 8}$ \\
\hline Total eggs upto 60 weeks of age(No.) & $63.27 \pm 1.60$ & $100.87 \pm 2.51$ & $77.60 \pm 1.74$ \\
\hline First egg weight(g) & $36.87 \pm 0.70$ & $42.47 \pm 0.97$ & $\mathbf{4 3 . 0 7} \pm 0.75$ \\
\hline Egg wt at 40 wks of age(g) & $47.47 \pm 0.62$ & $52.27 \pm 0.57$ & $51.80 \pm 0.44$ \\
\hline Egg wt at 60 wks of age (g) & $49.67 \pm 0.64$ & $53.07 \pm 0.55$ & $\mathbf{5 3 . 5 3 \pm 0 . 4 8}$ \\
\hline Shank length (mm) of adult male & $86.56 \pm 0.95$ & $91.50 \pm 0.65$ & $\mathbf{8 8 . 8 1} \pm 0.64$ \\
\hline Shank length (mm) of adult female & $73.69 \pm 0.79$ & $75.75 \pm 0.72$ & $77.06 \pm 0.84$ \\
\hline
\end{tabular}


Fig.1 Relative weight gain with age of the birds

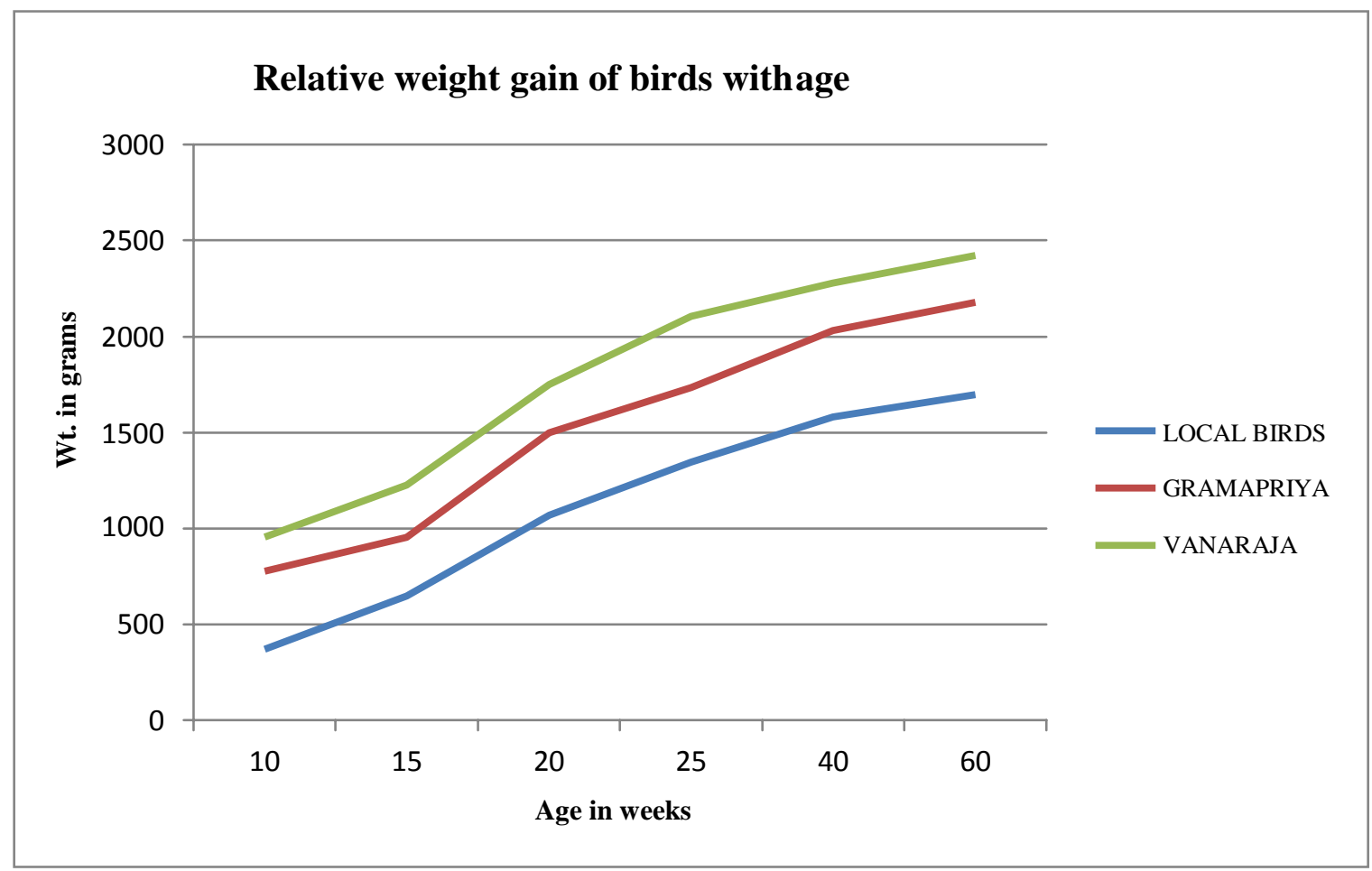

The performance of Vanaraja and Gramapriya was much better in comparison to desi birds in rural-hilly areas. The birds had adaptability in the local climatic conditions of Jammu province.

It can be concluded that performance of Vanaraja and Gramapriya in terms of age at first egg laying, egg production and body weight was much better in comparison to desi birds under backyard system of poultry rearing in Jammu Province. So, farmers from rural and tribal areas of Jammu Province can rear Vanaraja and Gramapriya birds for their livelihood and nutritional security.

\section{Acknowledgement}

We express our deep sense of gratitude to our Hon'ble Vice Chancellor for extending his administrative support and constant encouragement to carried out the research. We are highly thankful to IIFSR, Modipurum to provide financial assistance and technical guidance. The authors are also thankful to all who are directly or indirectly associated for carrying out the research findings.

\section{References}

Bhattacharya, M., Buragohain, R., Ahmed, F.A., Pathak, P.K. and Ghosh, M.K. 2005. Laying performance of Vanaraja birds in high altitude areas of Arunachal Pradesh under backyard system of rearing. Proceedings of XXIII IPSACON on Indian Poultry Production in changed global scenario: Challenges and opportunities. Hyderabad. Pp 198.

Bonnet S, Geraert PA, Lessire M, Carre B, Guillaumin S. 1997. Effect of high ambient temperature on feed digestibility in broilers. Poultry Science; 76(6):857-863.

Bujarbaruah, K.M. and Gupta, J.J. 2005. Family poultry for the development of 
NEH region. Poultry/articles/poultry development.php. cited from IPSACN 2005.

Haunshi, Santosh, Doley, Sunil and Shakuntala, I. 2009. Production performance of indigenous chicken of northeastern region and improved varieties developed for backyard farming. Indian Journal of Animal Sciences. 79(9): 901-05.

Kalita N, Pathak N and Islam R 2012b. Performance of Indigenous chicken in intensive system of management. Indian Veterinary Journal, 89: 43-44.

Kumar, A.S., Ngachan, S.V. and Sunder, G.S. 2005. Production performance of Vanaraja birds under traditional system of rearing in Manipur. Proceedings of XXIII Annual Conference of Indian Poultry Science Association on Indian Poultry Production in changed global scenario: Challenges and Opportunities. Hyderabad. pp. 205 (Abstr.).

Malik, S. and Singh, N.P. 2009. Rural Poultry Production in N.E. Region- Promotion of Backyard Poultry with Local and Improved Birds BYP Workshop/papers/SMalik.pdf.

Ramana DBV, Nirmala G, Maruthi V and Rao GR 2010. Performance of Vanaraja as backyard poultry. Indian Veterinary Journal, 87: 517-518.

Singh, R.V., Saxena, V.K. and Sharma, D. 2002. Technological developments in the poultry sub-sector; technology options for sustainable livestock production in India. Proceedings of the Workshop on Documentation, Adoption, and Impact of Livestock Technologies in India. pp 90-103.

Snedecor, G.W. and Cochran, W.G. 1989. Statistical Methods, $6^{\text {th }}$ edn., Oxford and IBH Publishing Co., Kolkata, Bombay and Delhi, pp 168-81.

Sreenivas D, Prakash MG, Mahender M, Chatterjee RN, Dasari S. 2013. Genetic analysis of egg quality traits in white leghorn chicken. Veterinary world, (5): 263-266.

\section{How to cite this article:}

Singh, P., D. Kachroo, N.P. Thakur, V. Khajuria, P. Kumar, Mahesh Kumar and Kour, G. 2018. Comparative Performance of Vanaraja, Gramapriya and Indigenous Desi Bird under Backyard System of Rearing in Jammu Province, India. Int.J.Curr.Microbiol.App.Sci. 7(02): 101-105. doi: https://doi.org/10.20546/ijcmas.2018.702.013 